\title{
An Ethical Approach to the 21st Century Humanity in the Face of Globalization: Towards Redefining the Meaning of Humanity in the Modern Times
}

\author{
George Ohabuenyi $\mathrm{Abah}^{1} \&$ Ignatius Ifeanyichukwu Ogbodo ${ }^{1}$ \\ ${ }^{1}$ Department of Philosophy, University of Nigeria, Nsukka, Nigeria \\ Correspondence: Ignatius Ifeanyichukwu Ogbodo, Department of Philosophy, University of Nigeria, Nsukka, \\ Nigeria
}

Received: January 17, 2020 Accepted: April 20, 2020 Online Published: April 30, 2020

doi:10.5539/gjhs.v12n5p103 URL: https://doi.org/10.5539/gjhs.v12n5p103

\begin{abstract}
Background: Historically, every century has a remarkable event for which it is known. These events, apart from giving a peculiar identity to a century, influences the religious, political, and socio-economic lives of the people. Apparently, the underlying element in the plurality of the world-views of the people of a century is the peculiar events of their time. In this light, the $21^{\text {st }}$ century is identical with globalization.

Methodology: The study used a qualitative design. The methods used were historical, expository, and critical. The historical method was used to trace some centuries before the $21^{\text {st }}$ century to examine their various understandings and approaches to the concept of humanity. The expository method was used to dissect the various anchors of humanity to see the relevance of a redefinition of humanity in the modern times. Finally, the critical method was used to access the $21^{\text {st }}$ century humans to know the expediency for a paradigm shift on the concept of humanity in the modern times.

Result: This paper argues that aside the positive effects of globalization, there is an urgent need to redefine the meaning of humanity that is already defaced by its inherent activities.

Conclusion: This research recommends that an ethical redress in the understanding of humanity in the face of today's globalization is expedient to promote reverence for human lives. This will help to avoid the collapse of this century into a game of exploitation of each other, the dead end of narcissism and invariably the dark age of a modern time.
\end{abstract}

Keywords: century, exploitation, globalization, humanity, modern times

\section{Introduction}

"What was God doing before He created the world?" This question has thrown so many religious experts into a millennia argument. To some, this question is not necessary because within his mortal frames, humans cannot comprehend eternal realities. To others, it is a theological question that digs around the personality of God which could be approached scripturally. To this latter group, so many religious leaders not only belong, but air their varied views. Pope Francis for one, opined that 'God was living in LOVE before the creation of the world because God is love.' Perhaps, to extend this overflowing love to something, God decided to create the universe; hence, creation is an extension of God's love. Apparently, these divergent opinions create a very good environment for assessing the question of existence which has troubled humans for ages. What God was doing before He created the world, is nothing short of the question of existence. The question creates two pictures of God and the Universe. God is seen as apart from, yet a part of the universe. He is apart from the universe because, his existence is not influenced by the universe nor is it a product of the universe. God assumes an independent existence without the universe. The latter has nothing to contribute to the existence of the former. Nevertheless, God is still part of the universe because, the latter has no independent existence without the former. God caused the universe into being. The Psalmist made this abundantly clear when he says: "The earth and its fullness belong to the Lord, the world and all that dwell in it. He founded it upon the ocean and set if firmly upon the waters....". (Psalm 24:1-2, The New Community Bible) Therefore, God is part of the universe because in religion, everything in creation has its meaning only when it is linked to God who caused its existence. 
Imperatively, humans are a part of God's universe. They are not only part of the universe, but were given a central position to tender or have "dominion" over all creatures (Cf. Gen. 1:26). This position of humans in the universe is not without an attendant implication as regards their relationship with God in one sense, and their relationship with their environment in another sense. In other words, it could be established that humanity bears its definition in its relationship with this bi-directional anchors namely, God and the Environment. The determinant factor so to say of the reasonability of humanity in any century is: human relationship with God on one hand, and their relationship with the environment on the other. Man is part of God and part of his environment. Hence, any careless relationship with either God or the Environment or both, will affect man and his humanity, and may perhaps lead man into the Hobbesian "state of nature," where the life of man would be 'solitary, poor, nasty, brutish and short.'(Cahn', 1995)A relationship that promotes man and his humanity must therefore involve both God and the environment. The question of existence therefore, is a question of human relationship with God (vertically) and their natural habitat (horizontally). And this relationship is clearly established in the first two dialogues of God with man in the scripture namely, "...Adam..., where are you?"3 (Gen. 3:9), and, "...Cain, where is your brother...?" (Gen. 4:9). While the first of the dialogues expresses a vertical dimension of the relationship, the second avers for a horizontal dimension of the relationship, signaling a concern for God and the environment respectively. Let us therefore examine these relationships to see how they affect man and his humanity especially in the modern times. The concept of man as we shall intermittently use it in this research refers to all human beings both male and female alike.

\subsection{Objective of the Study}

The main purpose of this study is to evaluate the $21^{\text {st }}$ century humanity in order to take a step towards redefining the meaning of humanity in the modern times.

\section{Methodology}

The study used a qualitative design. The methods used were historical, expository, and critical. The historical method was used to trace some centuries before the $21^{\text {st }}$ century to examine their various understandings and approaches to the concept of humanity. The expository method was used to dissect the various anchors of humanity to see the relevance of a redefinition of humanity in the modern times. Finally, the critical method was used to access the $21^{\text {st }}$ century humans to know the expediency for a paradigm shift on the concept of humanity in the modern times.

\subsection{Human Relationship With God in the Modern Times (the Vertical Axis)}

The very first dialogue of God with Adam in the scripture addresses the vertical relationship of man with God (Adam, where are you?). If the omniscient God was making inquiries about the whereabouts of the man, then the man took a step away from God thereby infringing on the relationship that bound them. This strayed step of man led to a fall that spanked a disordered universe. This scriptural account is a testimony that sets the pace that human alienation from God has only disaster as its result. A case study in the book of Judges exposed the terrible moments the Israelites passed through when they did what was evil in the sight of God and thus alienated from Him. Consequent upon their alienation from God, the hand of the Midianites (by divine design), lay heavily on them such that, for fear of the Midianites, the Israelites made for themselves shelters in the mountains, caves and strongholds. To cap it all, whenever the Israelites had sown their seed, the Midianites, the Amalekites and the people of the East would come up against the Israelites, encamp in their land and destroy all the crops as far as the entrance to Gaza (Judg. 6: 1-4). Of course, the story climaxed with the report that the Midianites subdued Israel and brought upon it so great a misery that the Israelites cried to the Lord (v. 6). These regrets were consequent upon their estrangement from God who earlier staked their defense from their foes. Now that they took their steps away from God, calamity became imminent. Hence, alienation from God is simply alienation from peace. It is a vote for a turbulent life of misery and hopelessness.

In the modern times, alienation from God is so evident that the modern man accepts God as a secondary value. His primary concerns are glued to modern developments where the philosophy of life is that of having, not that of being. But as Kevin Kruse puts it on the contrary, "Life is not about getting and having; it is about giving and being."(Kruse, n.d.) Corroborating this idea, Seneca, a Greek sage, as quoted by Ralph Waldo said that "God divided man into men that they may help each other"(Emerson, 1837). Amuluche-Greg Nnamani observed that, "in many parts of the world, especially in the West, there is an evident erosion of religious values and sensibilities, leading not only to the disregard of Christianity, but also to the denial of the existence of God. The voices of atheists, agnostics, and anti-church campaigners" according to him, "have become, not just loud in the media and global society, but also very audacious in their attempts to win more people on their sides." He finally averred that, "apparently, science and technology, democracy and entertainment, which constitute the main features of modern 
life, now command more respect and credibility than religion in most parts of the world" (Nnamani, 2013, p. $45^{\text {) }}$ True to fact is that there is a Religious crisis in the modern world that has succeeded in making God so hostile to man, resulting to man's hasty departure from the environment of God's existence. This perhaps is part of the bane of man's crisis today.

Diffusing into the profundity of its etymological nuance, religion is from the latin verb religare, meaning to "tie back, or tie tight;" or direct from the noun religio, meaning "obligation, or bond." Hence, it is on record that in the $5^{\text {th }}$ century, religion was used to showcase a relationship or bond between human beings and gods. Religion therefore, apart from its description of man's relationship with gods or God, significantly describes how man assumes God's existence, and how man uses this belief to order his life and the reality of the world. This means that in earlier centuries before us, man ordered his humanity by leaning on the relationship between him and God such that the story of his being is simply the story of God's Being. From the $5^{\text {th }}$ to the $14^{\text {th }}$ century, history holds that the existence of God was obvious, and his power over the happenings in the world was a matter of fact even in the whole Western World. Religion was then important for the explanation of every reality, geography, knowledge etc. Unfortunately, this belief began to know some cracks as time went on, as man continuously crowd out religious values and unsafely relapse into a prostrating helplessness enrobed in a seemingly unredeemable crisis, the unfortunate harvest of man's life without God.

The reformation of the $16^{\text {th }}$ century (when the authority and the hierarchy of the church was questioned and jettisoned respectively), the Age of Reason and the period of Enlightenment of the $17^{\text {th }}$ and $18^{\text {th }}$ centuries (when rationality and freedom became the highest instance of authority, giving rise to litany of revolutions), the scientific, technological, economic, civil and constitutional developments of the $19^{\text {th }}$ and $20^{\text {th }}$ centuries (when religion became an illusion, and God banned from human affairs), all gave rise to the crisis of the $21^{\text {st }}$ century man who is eluded by the question of existence, because he alienated himself from God. When the Russian astronauts came back from their first travel to the moon in the middle of the $20^{\text {th }}$ century for instance, one of them Yuri Gagarin declared to the people: we travelled to heaven and we did not find God and his angels over there. The implication of this report is that God does not exist because he assumed the moon to be heaven. Similar doubts about the existence of God started echoing the visions of Ludwig Feuerbach and Friedrich Nietzsche. For, while the former held that man created God, and not God man, or that God is but the projection of man, the latter affirmed that "God is dead." Finally, the proposition of Protagoras that "man is the measure of all things, of things that are that they are, of things that are not that they are not," (Copleston, 2003) became a testament in the modern times resulting to God being dethroned and stripped of all absolute authority over truth and reality; and liberty becoming a super god on throne commanding everybody's worship. This inheritance from the $20^{\text {th }}$ century makes existence in the $21^{\text {st }}$ century partly nebulous, as the $21^{\text {st }}$ century "homo sapiens" acquire a new essence in the "superman" with a relative perception of individualistic subjectivism.

The $21^{\text {st }}$ century is an age described as "the best of times and worst of times." In the words of Nnamani,

Never before have human beings advanced in science and technology like today, penetrating the space and mastering the weather, digitalizing every action and making distances virtually irrelevant by virtue of Information Technology. The entire world is now globalized and shrinking to a global village and overcoming the constraints of boundaries and distances; we are interconnected like never before. Today, the farthest part of the world is only a goggle search away. Yet, never before have human beings been so helpless in the face of their own ability to destroy themselves and the environment, so powerless in the attempt to control the side effects of their actions and the chain reactions of dangerous ideologies than today (Nnamani, 2013, p. 55)

This is because these discoveries and advancements led man into concluding that he is the measure of all things, God or no God. This position stifles human relationships with God. Humans thus assume an independent existence and alienate themselves from God and hence, started reaping the sour fruits of the "dictatorship of relativism" which they enthroned. In the words of Joseph Cardinal Ratzinger, "relativism has thus become the central problem for the faith at the present time" (Ratzinger, 1996). This is caused by what Marguerite Peters described as "a massive spread of new ideologies, values, concepts and languages, which are globally changing the life styles, cultures and mentalities of people in a quiet but powerfully binding way" (Peters, 2006). Apparently, man opts to be the measure of all things on individual capacities and refuses to be guided by authority, institution, tradition, law, conventional ethical norms, hierarchy, truth, etc. In other words, the core of this contemporary ideology is that which places the individual, rather than the institution (religious or non-religious), at the paradigm of that which is acceptable. This is the slippery terrain under which this century threads.

\subsection{Human Relationship with Their Environment in the Modern Times (the Horizontal Axis)}

"Cain, where is your brother" (Gen. 4: 9), is the second dialogue of God with man in the scripture. This question 
has a horizontal bent, signaling human relationships with each other and with all creatures in nature. This is because humans are products of their environments. Obviously, it was Cain's inability to understand his responsibility in his environment that led him into the killing of the brother, Abel. In a balanced judgement, when God demanded a sacrifice from them, both Cain and Abel made a harvest of the victims of their sacrifices from the environment. While Cain offered a technological sacrifice - the produce of the earth, Abel took to hunting games in order to offer an animal to God. Imperatively, one thing underlies these sacrifices made by the duo namely, both of them made a harvest from the environment - one, a produce of the earth, and the other, a wild animal. The rejection of Cain's product of the environment and the acceptance of Abel's product of the environment, brewed the cruel thought of bloodshed. The same harvest we make from our environment today is the root cause of so many ugly stories that cloud each day of the modern man. Just as it eluded Cain, the modern man still lacks the knowledge that the environment itself is a mystery.

The mysteries surrounding man and his environment has thrown philosophers into a millennia argument about what things really are like. It is this man's sense of wonder and curiosity about nature, expressed in the questions "what are things really like?" and "how can we explain the process of change in things?" that gave birth to philosophy. According to Plato, "wonder is the feeling of a philosopher, and philosophy begins in wonder" (Plato, n.d.). On the same page with Plato, Aristotle says that "it is owing to their wonder that men both now begin and at the first began to philosophize" (Aristotle, n.d.). Hence, philosophy could be seen in this light as an engagement of man's wisdom into inquiries. As Frost well-articulated,

The world in which you and I live was here long before us. How did it come to be? Was it created, or has it existed forever? Who or what made it, and how was it made? Are the trees, stars, men and women really "there" or are they mere creations of our minds or of the mind of God? How came this universe to be, and what is it made of? (Frost, 1962, p.5).

There is no one of us who has not wondered how the universe came into being. This world, with its flowers, rivers, rocks, sky, stars, sun, and moon, did not come about by mere chance, we reason. All that we see around us and all that we know of, must have become what it is today by some process. If we could understand this process, we could understand the nature of the universe. Consequent upon this, philosophers of different centuries and camps give varied interpretative opinions about man and his natural habitat. From the mythologies of Homer and Hesiod, through the wonders of the Ionian philosophers, to the pre-Socratic, and the Socratic, times, humans have featured varied interpretative opinions on the question of existence. And to the modern and contemporary times, the question of existence remains a fresh topic that confronts each generation with an unreserved wonder.

Be that as it may, philosophical expeditions on the question of existence arrived at MAN as its focus during the Socratic era. For, while the Pre-Socratic, early Greek Philosophers had concentrated on the nature of material universe and only discussed man as far as he could lead to understanding the material universe, the Socratic period shifted the attention of philosophy to the nature of man and discussed material universe to the extent that it could lead to the understanding of the nature of man. "When I consider thy heavens, the work of thy fingers, the moon and the stars, which thou hast ordained; what is man, that thou art mindful of him?" wrote the ancient Hebrew Psalmist many centuries ago (Psalm 8: 3). And his answer revealed a high opinion of the dignity of man. "Thou hast made him but little lower than God, and crowned him with glory and honour. Thou makest him to have dominion over the works of thy hands; thou hast put all things under his feet." (Psalm 8: 4)

Therefore, while the frontline philosophers focused their attention upon nature, the sophists and Socrates shifted the concerns of philosophy to the study of man. They opened up the problem of man's place in nature. They became skeptical of man's power to understand this universe and concentrated upon a study of man himself and man's relationship to other men. Instead of asking the large cosmic questions about the ultimate principle of things, philosophy became preoccupied with questions relating more directly to man's behavior. Of course, this is a submission to the fact that the universe is not as simple as we conceive it, but enshrined in a mystery beyond human calculations. Instead of a study about the relationship between man and his environment, philosophy took a lop-sided step of anthropocentrism. Though it was an extreme to study the universe without man as the first philosophers did, it was also another extreme to study man without his environment in the light of Socrates and other Anthropocentrists.

In short, for over 25 centuries, philosophy had a sustained emphasis on human beings without much considerations stretched to non-human nature. This sustained emphasis on human beings made moral philosophy in the Western tradition thoroughly anthropocentric or human-centered. Within these centuries, man was not only seen as the centre of the universe, but the only being in nature deserving moral consideration. And to cap it all, every other existence in nature is assumed to be instrumental to all human needs as man was considered the only end in himself. 
Hence, man has unlimited freedom to molest nature at any rate provided such actions serve his needs. In all, man has no moral responsibility at all over these other existences in nature. This view is replete in most of the traditional writings of the Western world. For instance, Thomas Aquinas' Humans as Moral Ends, Rene Descartes' Nonhumans as Machines, John Stuart Mill's The Amoral Status of Nature, John Locke's Nature as Economic Resource, Immanuel Kant's Indirect duties to Nonhumans, to mention but a few, are concepts we see in the Western world that create an anthropocentric circle around which the thinking man must revolve his meditations if he is to think perfectly. Philosophy hence became a bastion of anthropocentric thinking in the Western world at that point in time.

Consequent upon this gap in the latter study, man became wayward in his dealings with his environment. Man understood his "dominion" as a task for the reckless destruction of his environment. In his article: "The Historical Roots of Our Ecological Crisis," Lynn White argued that the tap root of the crisis we find in nature today, is found in the biblical mandate that human persons should "have dominion" over creation. Citing this article, Carol J. Dempsey and Russell A. Butkus quoted White as saying that it should be "laid at the door of the Bible and its interpretative communities the charge of generating the ideological framework for abuse of the earth" (Dempsey et al., 1999) The environment was given no consideration by man, and if considered at all, it was for instrumental reasons for man to realise his ends. Hence, instead of man to maintain a good relationship with nature for his peace, man alienates from nature and desacralizes it.

\subsection{Consequences of Human Alienations from God and the Environment on the $21^{\text {st }}$ Century Humanity}

When Adam alienated himself from God in the first dialogue, there were follow-up results that led Adam away from paradise. So was the same experience to Cain in the second dialogue that he became a wanderer as a consequence for shedding the blood of his brother Abel. The alienations of the $21^{\text {st }}$ century man from God and his environment cannot but bag him some consequences.

In the first place, since humans banned God out of their affairs, ours in the modern times is an age of man's inhumanity to man; the age when human life has lost its value for things. Unguarded attachments to material things have invariably enthroned things for persons and dethroned persons for things. For instance, kidnapping of human beings is enthroned for money; nudity is enthroned for entertainment; massacre of human lives is enthroned for boundary and grazing reasons; starvation of the greater number of humans in the society is enthroned for narcissistic reasons; human rituals and other manipulations is enthroned for political, economic and religious reasons. They are the unfortunate slides of human alienation from God, decaying to the displacement of persons with things. These ugly events not only question the meaning of humanity in the modern times, but seek a redefinition of humanity thus battered as it is today. Summarily, because man enthroned "liberty" as the $21^{\text {st }}$ century god to be worshipped by everyone in the era, we are now living in a world of competitive individualism, which in its decadence has carried the logic of individualism to an extreme of war of all against all; the pursuit of happiness to the dead end of a narcissistic preoccupation with the self. The selfish man of the modern times is in an opposite direction if not on a parallel lane with a generous God. The advent of Polarization, Xenophobia, Racism, etc; are all offshoots of the selfish man of the modern times. Hence, the $21^{\text {st }}$ century humans are strange bed-fellows to their humanity because they are strange bed-fellows to their creator.

On the other hand, the resultant effects of man's disregard of his environment, led to consumerism; unplanned migration from nature to culture with destruction of nature as the migrating root; undue exploitation of nature that has given vent to some natural hazards like erosion, global warming, climate change, pollution etc; that are overtaking man with an irredeemable destruction; use of heavy machines the effects of which nature feels so badly with a helpless surrender; and so on. To cite a practical example, a statistic evaluation about the nature of our environment in Nigeria was made in 2017 with an alarming result. The result show-cases that, "in the years ahead, we could face very sever ecological challenges that will impact negatively on our economy" (Nwodo, 2017).It becomes clear from the above report that we shall soon be out of things to exploit, except the very last dregs, and the most toxic and poisonous things of all. The oceans are full of plastic and the skies full of carbon. The only thing left to exploit is each other. Henceforth, google search is unnecessary to finding the cause of man's inhumanity to man that is replete in the modern times. Immanuel Kant warned against cruelty to animals which he foresaw as what would degenerate to cruelty to fellow humans. Once humans alienate from their environment and take to its destruction, they must face each other for the same destruction if what to destroy in the environment is exhausted. Just as Cain exploited Abel, so does it make rounds in the modern times that man's exploitation of man has become our common practice. This is because anthropocentrism caused our "Common Home" (Pope Francis, 2015, p. 18) to be seen as instrumental for serving humans ends only. This kind of ideology calls for an urgent redress. It could be established therefore from the foregoing that man's alienation from God and his environment has altered the 
meaning of humanity to man in the $21^{\text {st }}$ century.

\subsection{A Search for Redress on the Altered Meaning of Humanity in the Modern Times}

In a general sense, humanity is construed to mean the totality of human persons or human species that exist in an era. But in a particular bent to this work as its scope, humanity denotes all the people existing in this $21^{\text {st }}$ century, the modern era. So, the concept we actually project is the understanding that exists between the persons occupying the $21^{\text {st }}$ century universe. How do humans in this century see each other? Is the relationship among humans in this century something to write home about or something that needs a redress? Is the understanding we place on our fellow humans what it should be or is there a call for the redefinition of the meaning of humanity? These questions seek answers to address the meaning of humanity in the modern times.

There are so many good records in this century the abandonment of which is a kind of a lop-sided judgement. In the $21^{\text {st }}$ century, there are so many practices that unnerved the peace of the preceding centuries that have been tackled and conquered at least to a reasonable extent. For instance, Slavery is no longer in its pronounced terms as before; Universal human rights have been declared by the United Nations unlike before; There is zero world war in this century; Female rights to vote (women suffrage) is established unlike in some era where it was denied; Reduction in number of genocide is evident especially when compared to the stories of the past; Famine, diseases or war, do not constitute much threats again to the lives of this century, and even if they do, they are confronted head-on to extinction; and to cap it all, advancements in science and technology have made the world of the modern man a global village. Some opine strongly that the $21^{\text {st }}$ century is humanity's most significant, epic decade of transformation; one that will make the industrial revolution or the age of revolutions before it looks tiny and insignificant. These testimonies signal a vision of hope in our failing century.

Nonetheless, some on the contrary are of the opinion that the individual constitution of persons of this age could be viewed as turbulent, dramatic and intense. Hence, this century operates two poles of either a rise or a fall consequent upon her endowments. There is an air of transformation which can go one of two ways: either down into the abyss of violence, ignorance, war, and ruin, or up into a new era, a new phase of progress, and a new chapter in humanity's story. We may emerge wiser, mature and sophisticated as a species into higher, truer, more powerful forms of freedom, justice, truth, meaning and purpose. Yet, we may decay into a tireless but fruitless search for an evaporated peace. Therefore, the destiny of the century lies in our hands as we make our choices.

\section{Recommendations}

To escape the uncontrollable spread of man's inhumanity to man in our century, the following adoptions must be made: Firstly, there must be a reorientation on why we are occupying this universe at this point in time. This stimulates the religious background of man that should reconcile man's relationship with God. It is a relationship to God that can give vent to a relationship with man. Secondly, this century, this age of collapse, urgently calls for us to expand our moral horizons to include all of us. That is the only way we care about the planet, about inequality, about greed, about everything going wrong - by caring about everyone on it. We cannot call ourselves good and moral people but cannot care about anyone outside our families, tribes and nations. In this century, if we cannot care for everyone, no one will be cared for. We either stand together, or perish apart.

Also, the yawning gap between the rich and the poor must be closed by a kind of equality that rejects 'hunger' on the camp of some members of the society and 'excess' on the camp of others especially the few bourgeois. Also, we must reject exploitative paradigms, abuse, and violence as the ordering principle of our lives, societies, systems, and institutions. We have to reimagine and reinvent the ways that we do things collectively, in non-exploitative forms. Furthermore, we should be conscious of the fact that the world is out of fresh, unused resources with which to feed us, nurture us, and nourish us. And unless we get what that actually means, we are in for a nasty surprise. What it means is that we are going to have to learn to make much more from much less, or turn on each other and start taking things from our neighbours. The two options are: do more with less, or take from each other. Therefore, this century must fan cold every further destructive step on nature to avoid the destruction of ourselves when what to destroy in nature is no longer there.

\section{Summary and Conclusion}

The $21^{\text {st }}$ century man is a harvest of gifts with unimaginable endowments. Different from the preceding era, this century is most outstanding in so many discoveries and developments such that her era is just significant. For these arsenals of the modern times, some even ask whether there will still be need for another century after the $21^{\text {st }}$ century. However, just as it is the story of crisis where gifts abound, turbulent temptations abound in this century that threaten the true meaning of humanity by man. The $21^{\text {st }}$ century man is "godless" by virtue of his alienation from God who is the source of his existence. He is also "anthropocentric" in his alienation from his environment by 
the destructions he conducts on nature. These bi-directional alienations have led him into a wrong notion of humanity which he treats as things not persons due to his selfish inclinations. Therefore, this is an age of man's inhumanity to man - a plague of suffering for humanity.

But all hope is not lost yet if the modern humans will redirect their steps into reconciling with God and the environment. This can be achieved by a reorientation of the wrong notions of humanity that already becloud their senses. Humans must eschew the paradigm of extortion, exploitation and selfishness, and seek equality and peace for all. This will enhance a sustainable development of their environment giving room for their peace here and now, and the peace of their generations hereafter. Otherwise, they may eternally seek for a peace that will never come their way if they remain resolute in their alienations and the consequent unholy practices.

\section{Competing Interests Statement}

The authors declare that there are no competing or potential conflicts of interest.

\section{References}

Aristotle, Metaphysics, Bk 1, ch. 2 [982b12].

Cahn, S. M. (ed., 1995). Classics of Western Philosophy (4th ed., P. 474). Hackett Publishing Company, Inc.

Copleston, F. (2003). A History of Philosophy: Greece and Rome (p. 87). London: Bloomsbury Pub. Plc..

Dempsey C.J. et al, (eds., 1999). All Creation is Groaning: An Interdisciplinary Vision for Life in a Sacred Universe. A Michael Glazier Book published by The Liturgical Press.

Emerson, R. W. (29 July, 1837). Nature, Addresses and Lectures. Complete Works, 1, 82, note 1.

Frost, S. E. Jr. (1962). Basic Teachings of the Great Philosophers. Garden City, New York: Doubleday.

Nnamani, A. (2013). The Crisis of Religion and the Challenges of Christian Faith in the Contemporary World. In Nnamani, A. and Ihensekhien, M. (Eds.), The Catholic Faith in the face of Changing Values (p. 45). Benin-city: Floreat Systems Limited: Benin City.

Nwodo, N. Jnr. (2017). 50 Years After Biafra: Reflections and Hopes. A paper presented at the Yar'Adua Centre on 50 Years of Biafra.

Peters, M. (2006). The New Global Ethic: Challenges for the Church. Institute for intercultural Dialogue Dynamics, 16.

Plato, Theaetetus, Section 1, [155c6]

Pope, F. (2015). Laudato Si' On the Care for Our Common Home. St Pauls in Nigeria by arrangement with Libreria Editrice Vaticana.

Quote by Kevin Kruse: "Life isn't about getting and having, it's ... Retrieved from www.goodreads.com.

Ratzinger, J. (1996). Relativism: The Central Problem for Faith Today. An address during the meeting of the Congregation for the Doctrine of the Faith with the presidents of the Doctrinal Commissions of the Bishop's Conferences of Latin America, held in Guadalajara, Mexico, May, 1996.

The New Community Bible. (2015). St. Paul Publication Australia.

\section{Copyrights}

Copyright for this article is retained by the author(s), with first publication rights granted to the journal.

This is an open-access article distributed under the terms and conditions of the Creative Commons Attribution license (http://creativecommons.org/licenses/by/4.0/). 